\title{
Karakteristik organoleptik pada produk olahan stik biji nangka
}

Organoleptic characteristics of jackfruit stick products

\author{
Ningrum Dwi Hastutik ${ }^{1)}$ \\ ${ }^{1}$ Program Studi Teknologi Pengolahan Hasil Perkebunan, Politeknik Negeri Ketapang \\ Email: ningrumdh@gmail.com
}

Informasi Artikel:

Dikirim: 01/03/2020; ditinjau: 02/03/2020; disetujui: 20/03/2020

\begin{abstract}
Jackfruit seeds have high nutritional content such as carbohydrates, and protein, so they can be used as potential food. Processing jackfruit seeds into food products is one form of business utilizing jackfruit seed waste as an alternative to adding new food sources. The purpose of this study was to determine the organoleptic characteristics of jackfruit seed stick products. Organoleptic test using friedman test with $\alpha=0.05$ and determining the best treatment using the effectiveness index. The results showed that the best organoleptic test was obtained from jackfruit seed stick products with a product value of 0.610 with a mean value of the panelists' preference for taste of 4.40; color of 3.92 and flavour of 2.48
\end{abstract}

Key words: jackfruit seeds, flour, sticks

\begin{abstract}
ABSTRAK
Biji nangka memiliki kandungan gizi yang tinggi seperti karbohidrat, dan protein, sehingga dapat dimanfaatkan sebagai bahan pangan yang potensial. Pengolahan biji nangka menjadi produk makanan merupakan salah satu bentuk usaha memanfaatkan limbah biji nangka sebagai alternatif penambah sumber bahan pangan baru. Tujuan dari penelitian ini adalah untuk mengetahui karakteristik organoleptik terhadap produk olahan stik biji nangka. Uji organoleptik menggunakan uji friedman dengan $\alpha=0,05$ dan penentuan perlakuan terbaik menggunakan indeks efektivitas. Hasil penelitian menunjukkan bahwa uji organoleptik terbaik diperoleh dari kombinasi perlakuan tepung biji nangka $25 \%$ dan tepung tapioka $75 \%$ dengan karakteristik rerata nilai tingkat kesukaan panelis terhadap rasa 6,20, warna 6,16 dan aroma 6,08.
\end{abstract}

Kata kunci: biji nangka, tepung, stik.

\section{PENDAHULUAN}

Biji nangka mempunyai kandungan gizi yang sangat tinggi dan dapat digunakan sebagai bahan pangan potensial. Biji nangka merupakan sumber mineral yang baik (Gupta et al., 2011; Abedin et al., 2012) selain dapat dimakan dalam bentuk utuh, biji nangka dapat diolah menjadi keripik yang enak dan bergizi (Astawan, 2007). Biji buah nangka kaya gizi, terutama kandungan karbohidrat, potassium/kalium, fosfor, dan lemak.
Kandungan energi (165 kcal) dan karbohidrat (36,7 kcal) biji nangka yang cukup tinggi dibandingkan dengan kandungan yang sama dari nangka muda dan nangka matang membuat biji nangka menjadi pilihan bagi masyarakat di Asia Selatan untuk menjadikan biji nangka sebagai salah satu kudapan penangkal rasa lapar. Kandungan minyak biji nangka mencapai 11,39\% (Sindumatra, 2012; dewi, 2013).

Komposisi kimianya biji nangka mengandung pati cukup tinggi, yaitu sekitar 
40-50\%, sehingga sangat berpotensi sebagai sumber pati (Mandruga et al., 2014; Zhang et al., 2018). Kandungan yang terdapat di dalam biji nangka yaitu energi (165 kkal), protein $(4,2$ gr $)$, lemak (0,1 gr), karbohidrat (36,7 gr), kalsium (33 mg), fosfor (200 mg), besi $(1 \mathrm{mg})$, vitamin $\mathrm{B} 1(0,2 \mathrm{mg})$, vitamin C (10 mg), dan air $(57,7$ gr). Biji nangka merupakan sumber karbohidrat $(36,7$ gr/100 gr), protein (4,2 d/100 gr), dan energi (165 $\mathrm{kkal} / 100 \mathrm{gr}$ ), sehingga dapat dimanfaatkan sebagai bahan pangan yang potensial. Biji nangka juga merupakan sumber mineral yang baik. Di dalam 100 gr biji nangka terkandung fosfor (200 mg), kalsium (33 mg), dan besi (1,0 mg) (Nuraini, 2012).

Pengolahan biji nangka menjadi produk makanan merupakan salah satu bentuk usaha memanfaatkan limbah biji nangka sebagai alternatif penambah sumber bahan pangan baru. Salah satu cara yang dapat dilakukan adalah dengan memanfaatkan biji nangka menjadi tepung (Rizal et al., 2012). Tepung biji nangka dibuat dengan cara memilih biji nangka yang baik terutama pada teksturnya, lalu mencuci biji nangka di atas air mengalir. Setelah itu biji nangka direbus hingga kulit ari dari biji nangka terkelupas. Lalu biji nangka dibersihkan, dan dipotong-potong atau diiris tipis - tipis. Selanjutnya biji nangka dipotong potong kecil lalu dijemur di bawah terik matahari setelah kering biji nangka digiling (diselip) hingga halus (Kusumawati et al., 2012).

Pemanfaatan tepung biji nangka dapat digunakan sebagai bahan pengolahan pangan lebih lanjut seperti kue kering satu, keripik, dan kerupuk yang berbasis pada bahan tepung-tepungan. Biji nangka dimanfaatkan oleh sebagian kecil masyarakat sebagai bahan pada pembuatan kue, tempe, yoghurt dan sebagainya. Tetapi pada kesempatan kali ini, biji nangka akan diolah menjadi stik sebagai salah satu makanan ringan (cemilan) yang banyak digemari oleh masyarakat. Alasan pengolahan biji nangka sebagai stik dikarenakan limbah biji nangka kebanyakan langsung di buang dan tidak dimanfaatkan, karena mayoritas masyarakat lebih memilih makanan siap saji daripada harus repot mengolahnya. Selain itu makanan berupa stik juga banyak digemari oleh masyarakat (Qomari, 2013).

Stik merupakan makanan ringan atau jenis kue kering dengan bahan dasar tepung terigu, tepung tapioka atau tepung sagu, lemak, telur serta air, yang berbentuk pipih,atau bulat panjang dan dengan cara penyelesaiannya dengan cara digoreng, mempunyai rasa gurih serta bertekstur renyah sehingga banyak disukai masyarakat. Adonan stik tergolong dalam adonan gorengan jenis padat. Stik dapat dihidangkan setiap saat sebagai makanan ringan (cemilan), sebagai teman minum teh dan dapat sebagai buah tangan saat mengunjungi saudara. Stik merupakan kata sarapan dari bahasa inggris yang artinya tongkat atau sesuatu yang berbentuk seperti batang. Makanan ini bentuknya pipih panjang menyerupai tongkat maka makanan ini disebut dengan stik (Ramadani dan Suhairi, 2018).

\section{BAHAN DAN METODE}

\section{Bahan}

Bahan yang digunakan dalam penelitian ini adalah buah tepung biji nangka, tepung maizena, tepung tapioka, garam, telur, bawang putih, soda kue, dan margarin

\section{Alat}

Alat-alat yang digunakan dalam penelitian ini meliputi, penggiling mie, baskom, sealer, wajan, kompor, nampan, timbangan, meja lipat, penggiling daging, spatula, pisau, serok, gunting, dan tabung gas LPG

\section{Rancangan penelitian}

Rancangan penelitian ini menggunakan Rancangan Acak Kelompok (RAK) Faktorial. Terdiri dari 2 faktor, di mana semua faktor terdiri dari tiga level. Kombinasi perlakuan yang didapatkan adalah tepung biji nangka $25 \%$ dan tepung maizena $75 \%$ (P1N1), tepung biji nangka 50\% dan tepung maizena $50 \%(\mathrm{P} 1 \mathrm{~N} 2)$, tepung biji nangka $75 \%$ dan tepung maizena $25 \%$ (P1N3), tepung biji nangka $25 \%$ dan tepung tapioka $75 \%$ (P2N1), tepung biji nangka 50\% 
dan tepung tapioka 50\% (P2N2), dan tepung biji nangka $75 \%$ dan tepung tapioka $25 \%$ (P2N3)

\section{Pengamatan}

Pengamatan dilakukan terhadap enam kombinasi perlakuan dengan uji organoleptik meliputi; warna, rasa dan aroma serta menggunakan 25 panelis yang tidak terlatih.

\section{Analisis data}

Data hasil uji organoleptik dianalisis dengan metode statistik non parametrik menggunakan Uji Friedman dengan $\alpha=0,05$, sedangkan perlakuan terbaik menggunakan indeks efektivitas.

\section{HASIL DAN PEMBAHASAN}

\section{Warna}

Hasil uji organoleptik menyajikan bahwa rerata rangking kesukaan panelis terhadap warna dari kombinasi perlakuan tepung limbah biji nangka dengan tepung tapioka dan maizena berkisar antara 3,646,16. Semakin tinggi rerata rangking kesukaan panelis, maka tingkat kesukaan panelis terhadap warna semakin besar. Tabel 1 memperlihatkan rerata rangking tingkat kesukaan panelis terhadap warna.

Tabel 1. Rerata tingkat kesukaan panelis terhadap warna

\begin{tabular}{lc}
\hline \multicolumn{1}{c}{ Kombinasi perlakuan } & Rerata \\
\hline tepung biji nangka 25\% dan tepung maizena 75\% (P1N1) & 4,88 \\
tepung biji nangka 50\% dan tepung maizena 50\% (P1N2) & 4,04 \\
tepung biji nangka 75\% dan tepung maizena 25\% (P1N3) & 3,72 \\
tepung biji nangka 25\% dan tepung tapioka 75\% (P2N1) & 6,16 \\
tepung biji nangka 50\% dan tepung tapioka 50\% (P2N2) & 4,52 \\
tepung biji nangka 75\% dan tepung tapioka 25\% (P2N3) & 3,64 \\
\hline
\end{tabular}

Tabel 1 memperlihatkan rerata nilai kesukaan panelis terhadap warna pada berbagai kombinasi perlakuan mempunyai nilai terendah sebesar 3,64 dari kombinasi perlakuan tepung biji nangka $75 \%$ dan tepung tapioka $25 \%$ (P2N3). Nilai tertinggi tingkat kesukaan panelis terhadap warna sebesar 6,16 didapatkan dari tepung biji nangka $25 \%$ dan tepung tapioka $75 \%$ (P2N1).

Hasil analisis Uji Friedman $(\alpha=0,05)$ berdasarkan uji perbandingan pada berbagai kombinasi perlakuan memberikan pengaruh nyata terhadap rerata kesukaan warna terhadap kombinasi perlakuan tepung limbah biji nangka dengan tepung tapioka dan maizena. Kombinasi perlakuan terbaik tingkat kesukaan panelis terhadap warna diperoleh dari kombinasi perlakuan tepung biji nangka $25 \%$ dan tepung tapioka $75 \%$ (P2N1), warna yang ditimbulkan oleh produk stik biji nangka sangat menarik yaitu seperti perpaduan antara kuning bening.

\section{Rasa}

Hasil uji organoleptik menyajikan bahwa rerata rangking kesukaan panelis terhadap rasa dari kombinasi perlakuan tepung limbah biji nangka dengan tepung tapioka dan maizena berkisar antara 3,646,2 . Semakin tinggi rerata rangking kesukaan panelis, maka tingkat kesukaan panelis terhadap rasa semakin besar. Tabel 2 memperlihatkan rerata rangking tingkat kesukaan panelis terhadap rasa.

Tabel 2. Rerata tingkat kesukaan panelis terhadap rasa

\begin{tabular}{lc}
\hline \multicolumn{1}{c}{ Kombinasi perlakuan } & Rerata \\
\hline tepung biji nangka 25\% dan tepung maizena 75\% (P1N1) & 4,80 \\
tepung biji nangka 50\% dan tepung maizena 50\% (P1N2) & 4,04 \\
tepung biji nangka 75\% dan tepung maizena 25\% (P1N3) & 3,80 \\
tepung biji nangka 25\% dan tepung tapioka 75\% (P2N1) & 6,20 \\
tepung biji nangka 50\% dan tepung tapioka 50\% (P2N2) & 4,52 \\
tepung biji nangka 75\% dan tepung tapioka 25\% (P2N3) & 3,64 \\
\hline
\end{tabular}


Tabel 2 memperlihatkan rerata nilai kesukaan panelis terhadap rasa pada berbagai kombinasi perlakuan mempunyai nilai terendah sebesar 3,64 dari kombinasi perlakuan tepung biji nangka $75 \%$ dan tepung tapioka $25 \%$ (P2N3). Nilai tertinggi tingkat kesukaan panelis terhadap rasa 6,20 didapatkan dari tepung biji nangka $25 \%$ dan tepung tapioka $75 \%(\mathrm{P} 2 \mathrm{~N} 1)$.

Hasil analisis Uji Friedman $(\alpha=0,05)$ berdasarkan uji perbandingan pada berbagai kombinasi perlakuan memberikan pengaruh nyata terhadap rerata kesukaan rasa terhadap kombinasi perlakuan tepung limbah biji nangka dengan tepung tapioka dan maizena. Kombinasi perlakuan terbaik tingkat kesukaan panelis terhadap rasa diperoleh dari kombinasi perlakuan tepung biji nangka $25 \%$ dan tepung tapioka $75 \%$ (P2N1), rasa yang ditimbulkan oleh produk stik biji nangka sangat menarik yaitu rasanya renyah.

\section{Aroma}

Hasil uji organoleptik menyajikan bahwa rerata rangking kesukaan panelis terhadap aroma dari kombinasi perlakuan tepung limbah biji nangka dengan tepung tapioka dan maizena berkisar antara 3,286,08 Semakin tinggi rerata rangking kesukaan panelis, maka tingkat kesukaan panelis terhadap aroma semakin besar. Tabel 3 memperlihatkan rerata rangking tingkat kesukaan panelis terhadap aroma.

Tabel 3. Rerata tingkat kesukaan panelis terhadap aroma

\begin{tabular}{lc}
\hline \multicolumn{1}{c}{ Kombinasi perlakuan } & Rerata \\
\hline tepung biji nangka 25\% dan tepung maizena 75\% (P1N1) & 5,60 \\
tepung biji nangka 50\% dan tepung maizena 50\% (P1N2) & 3,92 \\
tepung biji nangka 75\% dan tepung maizena 25\% (P1N3) & 4,60 \\
tepung biji nangka 25\% dan tepung tapioka 75\% (P2N1) & 6,08 \\
tepung biji nangka 50\% dan tepung tapioka 50\% (P2N2) & 3,88 \\
tepung biji nangka 75\% dan tepung tapioka 25\% (P2N3) & 3,28 \\
\hline
\end{tabular}

Tabel 3 memperlihatkan rerata nilai kesukaan panelis terhadap aroma pada berbagai kombinasi perlakuan mempunyai nilai terendah sebesar 3,28 dari kombinasi perlakuan tepung biji nangka $75 \%$ dan tepung tapioka $25 \%$ (P2N3). Nilai tertinggi tingkat kesukaan panelis terhadap rasa 6,08 didapatkan dari tepung biji nangka $25 \%$ dan tepung tapioka $75 \%(\mathrm{P} 2 \mathrm{~N} 1)$.

Hasil analisis Uji Friedman $(\alpha=0,05)$ berdasarkan uji perbandingan pada berbagai kombinasi perlakuan memberikan pengaruh nyata terhadap rerata kesukaan aroma terhadap kombinasi perlakuan tepung limbah biji nangka dengan tepung tapioka dan maizena. Kombinasi perlakuan terbaik tingkat kesukaan panelis terhadap aroma diperoleh dari kombinasi perlakuan tepung biji nangka $25 \%$ dan tepung tapioka $75 \%$ (P2N1), aroma yang ditimbulkan oleh produk stik biji nangka sangat menarik yaitu seperti perpaduan antara kuning bening.

\section{Pemilihan perlakuan terbaik parameter organoleptik}

Penentuan perlakuan terbaik berbagai kombinasi perlakuan tepung limbah biji nangka dengan tepung tapioka dan maizena dilakukan dengan menggunakan metode indeks efektivitas (Susrini, 2005). Metode ini dilakukan pada parameter organoleptik. Adapun parameter organoleptik meliputi; rasa, warna dan aroma. Penilaian perlakuan terbaik disajikan pada Tabel 4. 
Tabel 4 Perlakuan terbaik uji organoleptik

\begin{tabular}{lcccc}
\hline \multicolumn{1}{c}{ Kombinasi perlakuan } & Rasa & Warna & Aroma & $\begin{array}{c}\text { Nilai } \\
\text { Produk }\end{array}$ \\
\hline tepung biji nangka 25\% dan tepung maizena 75\% (P1N1) & 4,80 & 4,88 & 5,60 & 0,55 \\
tepung biji nangka 50\% dan tepung maizena 50\% (P1N2) & 4,04 & 4,04 & 3,92 & 0,17 \\
tepung biji nangka 75\% dan tepung maizena 25\% (P1N3) & 3,80 & 3,72 & 4,60 & 0,14 \\
tepung biji nangka 25\% dan tepung tapioka 75\% (P2N1) & $\mathbf{6 , 2 0}$ & $\mathbf{6 , 1 6}$ & $\mathbf{6 , 0 8}$ & $\mathbf{1 , 0 0 *}$ \\
tepung biji nangka 50\% dan tepung tapioka 50\% (P2N2) & 4,52 & 4,52 & 3,88 & 0,32 \\
tepung biji nangka 75\% dan tepung tapioka 25\% (P2N3) & 3,64 & 3,64 & 3,28 & 0,00 \\
\hline
\end{tabular}

$*$ = perlakuan terbaik

Tabel 4 memperlihatkan kombinasi perlakuan terbaik diperoleh dari kombinasi perlakuan tepung biji nangka $25 \%$ dan tepung tapioka $75 \%$ (P2N1) dengan nilai produk sebesar 1,00 dengan karakteristik sebagai berikut: rerata nilai tingkat kesukaan panelis terhadap rasa 6,20 ; warna 6,16 dan aroma 6,08.

\section{KESIMPULAN}

Karakteristik organoleptik terbaik diperoleh dari tepung biji nangka 25\% dan tepung tapioka $75 \%(\mathrm{P} 2 \mathrm{~N} 1)$ dengan nilai produk sebesar 1,00 meliputi rasa sebesar 4,40, warna sebesar 3,92 dan aroma 2,48.

\section{UCAPAN TERIMA KASIH}

Penulis mengucapkan terima kasih kepada seluruh pihak yang telah membantu dalam pelaksanaan kegiatan penelitian dan seluruh pihak yang telah membantu dalam penelitian ini terutama kepada Politeknik Negeri Ketapang.

\section{DAFTAR PUSTAKA}

Abedin, M. S., Nuruddin, M. M., Ahmed, K. U., \& Hossain, A. (2012). Nutritive compositions of locally available jackfruit seeds (Artocarpus heterophyllus) in Bangladesh. International Journal of Biosciences, 2(8), 1-7.

Astawan, M. (2007). Tetap sehat dengan produk makanan olahan. Tiga Serangkai. Surakarta.

Dewi, K. W. (2013). Pemanfaatan biji nangka (Artocarpus heterophyllus) sebagai Bahan baku pembuatan es krim dengan pewarna alami Kunyit (Curcuma domestica) [Doctoral dissertation], Universitas Muhammadiyah Surakarta.

Gupta, D., Mann, S., Sood, A., \& Gupta, R. K. (2011). Phytochemical, nutritional and antioxidant activity evaluation of seeds of jackfruit (Artocarpus heterophyllus Lam.). International Journal of Pharma and Bio Sciences, 2(4), 336-345.

Kusumawati, D.D., Amanto, B.S. \& Muhammad, D.R. (2012). Pengaruh perlakuan pendahuluan dan suhu pengeringan terhadap sifat fisik, kimia, dan sensori tepung biji nangka (Artocarpus heterophyllus). Jurnal Teknosains Pangan 1(1), 41-48.

Madruga, M. S., de Albuquerque, F. S. M., Silva, I. R. A., do Amaral, D. S., Magnani, M., \& Neto, V. Q. (2014). Chemical, morphological and functional properties of Brazilian jackfruit (Artocarpus heterophyllus L.) seeds starch. Food chemistry, 143, 440445.

Nuraini, D.N. (2011). Aneka Manfaat Bijibijian. Sidoarjo: Penerbit Gava Media.

Qomari, F. (2013). Pengaruh substitusi tepung biji nangka terhadap sifat organoleptik dan sifat kimia kerupuk. Jurnal Tata Boga, 2(1), 176 182.

Ramadani, S., \& Suhairi, L. (2018). Karakteristik organoleptik stik biji nangka (artocarpus heterophyllus) dalam pembuatan stik biji nangka. Jurnal Ilmiah Mahasiswa Pendidikan Kesejahteraan Keluarga, 3(2), 48-56. 
Restu, N., Damiati, M.K. \& Ekayani, I.A.P. H. (2015). Pemanfaatan tepung biji nangka menjadi kue pia kering. Bosaparis 3(1), 1-8. Doi: http://dx.doi.org/10.23887/jjpkk.v3i1.4 853

Rizal, S., Surmarlan, S.H. \& Yulianingsih, R. (2013). Pengaruh konsentrasi natrium bisulfit dan suhu pengeringan terhadap sifat fisik-kimia tepung biji nangka (Artocarpus heterophyllus). Jurnal Bioproses Komoditas Tropis, 1(2), 110.

Santoso, M. T., Hidayati, L., \& Sudjarwati, R. (2015). Pengaruh perlakuan pembuatan tepung biji nangka terhadap kualitas cookies lidah kucing tepung biji nangka. Teknologi dan Kejuruan, 37(2), 167-178. Doi: http://dx.doi.org/10.17977/tk.v37i2.443 3

Sindumarta, D. (2012). Awet muda dengan durian dan buah-buahan khas nusantara. Yogyakarta: Grafindo Litera Media.
Supriadi, A., \& Pangesti L.T (2014). Pengaruh substitusi tepung biji nangka (Artocarpus heterphyllus) terhadap mutu organoleptik kue onde-onde ketawa. Jurnal Tata Boga, 3(1), 225233.

Utomo, D., Murtadlo, K., \& Novia, C. (2016). Pemanfaatan limbah biji nangka menjadi dodol dan kerupuk. Teknologi Pangan: Media Informasi dan Komunikasi Ilmiah Teknologi Pertanian, 7(3), 114-117.

Zhang, Y., Zhang, Y., Xu, F., Li, S., \& Tan, L. (2018). Structural characterization of starches from Chinese jackfruit seeds (Artocarpus heterophyllus Lam). Food Hydrocolloids, 80, 141-148. 